\title{
Paideusis
}

\section{Can Leadership be Taught?}

\section{A. Howard}

Volume 6, Number 1, 1992

URI: https://id.erudit.org/iderudit/1073342ar

DOI: https://doi.org/10.7202/1073342ar

See table of contents

Publisher(s)

Canadian Philosophy of Education Society

ISSN

0838-4517 (print)

1916-0348 (digital)

Explore this journal

Cite this article

Howard, V. (1992). Can Leadership be Taught? Paideusis, 6(1), 3-15.

https://doi.org/10.7202/1073342ar

This document is protected by copyright law. Use of the services of Erudit (including reproduction) is subject to its terms and conditions, which can be viewed online.

https://apropos.erudit.org/en/users/policy-on-use/ 


\section{Can Leadership be Taught?}

\section{V.A. Howard, Harvard University}

\section{A Matter of Principle}

Despite dissenting voices from within their ranks, ${ }^{1}$ social scientists appear generally agreed that leadership can be taught if only we first study it properly: that is, straighten our definitions, identify the "skills" of successful incumbents, adopt an appropriate analytical "model" to weigh and co-vary those skills, then instruct aspiring leaders in how to acquire and deploy them in real life. Meanwhile, since about the late fifties, educators, government, military, and business people have eagerly devoured the results of successive factor analytical, corporate cultural, "transactional," or "interpersonal" studies hoping to find there both understanding and procedural knowledge of the elusive phenomena of leadership. And what do they find? As one psychologist puts it, "Four decades of research on leadership have produced a bewildering mass of findings. . . [but] the endless accumulation of empirical data has not produced an integrated understanding of leadership." 2 Others even suggest abandoning the term 'leadership' altogether on grounds that the phenomena of leadership are much too complex and contingent to be encompassed by a single vague and ambiguous term. ${ }^{3}$

Of course, Baconian science never produced an "integrated understanding" of anything; and the suggestion that we abandon the term 'leadership' is a bit like suggesting that we abandon the term 'motion' in physics because the phenomena of motion are so complex. Still, the gist of these complaints is plain: how can we pretend to teach what we understand so poorly?

I am reminded of a satirical little piece of unknown origin from my graduate days about the scientific study of "ambulation per se" as a necessary condition of truly informed instruction in "scientific walking" versus mere "folk walking" picked up willy-nilly from parents and personal struggle. So, I shall not attempt to steer a methodological course between the Scylla of factor analysis and the Chrybdis of ethnographic studies. Rather, I shall address the question: Is it possible in principle to teach leadership as a set of skills, even if we knew what they were? I think not; and that shall be the thrust of my argument, not, I hasten to add, to make philosophers kings (God forbid!) but, instead, to make social scientists and kings a bit more philosophical.

\section{The Language of Leadership}

First, the idea of defining leadership for scientific purposes is silly. Leadership, like creativity or human potential, is not a scientific concept. It belongs in ordinary discourse about practical affairs and achievements-and failures. The best we can do is to reconnoitre the conceptual landscape of leadership and pick out aspects of that landscape for closer study, scientifically, philosophically, and historically. So what is that landscape?

Even the briefest look around reveals a rough topography of intersecting verbs, nouns, adjectives, and their compounds such as 'to lead' (guide), 'lead on' (lure, entice), 'lead off' (begin), 'lead in' (introduce), 'a lead' (guidance given or an example), 'lead' (of five minutes), 'leader' (of government, or or- 
chestra), 'leading edge), 'leading man/woman,' 'leading tone' (7th interval), and 'leading place, position' (in or taking the lead, leadership), 'leading light' (person of influence or vision). ${ }^{4}$ The connections to place, position, influence, example, and guidance naturally tie the concepts of leading, leader, and leadership to authority, influence, and power. And it is the latter-the ranges and relations among leadership, authority, influence, and power-that are most relevant.

For the moment, note that leadership can be personal, as with a single figurehead, collective, as with a leading clique or parliament, or impersonal, as by certain ideas, past achievements, or precedents. That is, while the questions of who is leading and how tend to dominate discussions of leadership in business, education, and government, questions of what is leading and why are equally relevant. For example, leadership in the realms of art, science, and literature is more indirect, by means of works and ideas. In those realms, the quick and the dead are on equal footing through their works, particularly over the long run. This is leadership by influence-action upon others "perceptible only its effects." 5 Even farther removed from the domain of personal or group leadership are certain "leading" (dominant, causal) trends in economics and politics that often outrun the strivings or intentions of their initiators, if indeed, there were any. But, you will say, are these not the accomplishments of people? Accomplishments of people, yes, sometimes, sometimes not, and failures too; and therein lies another distinction.

Leadership, like a bost of other words-education, creativity, discovery, teaching-refers both to certain tasks or activities, on the one hand, and to certain achievements or outcomes on the other. Which is to say that leadership is both a "process' and a "product" word, which means that what is leading and why are equally significant questions to ask as who is leading and how. On tasks and their corresponding achievements, the philosopher Gilbert Ryle remarks:

One big difference between the logical force of a task verb (e.g., listening) and that of a corresponding achievement verb (e.g., hearing) is that in applying an achievement verb we are asserting that some state of affairs obtains over and above that which consists in the performance, if any, of the subservient task activity. For a runner to win, not only must he run but also his rivals must be at the tape later than he. . An autobiographical account of the agent's exertions and feelings does not by itself tell whether he has brought off what he was trying to bring off. . I withdraw my claim to have seen a misprint, or convinced the voter, if I find that there was no misprint, or that the voter has cast his vote for my opponent. ${ }^{6}$

Two noteworthy consequences of this distinction are, first, that success may be partly or wholly ascribed to luck or some other cause, though not always, of course. "A clock may be repaired by a random jolt and the treasure may be unearthed by the first spade-thrust." Second, some achievements "are prefaced by no task performances. We sometimes find things without searching, secure appointments without applying, and arrive at true conclusions without having weighed the evidence." 7 The implications for leadership studies are clear: events ascribed to effective leadership may have other causes-a point often made in the literature; but also effective leadership, as an achievement, may also come about less by careful judgement or wisdom than by being in the 
right place at the right time and having made the right move or call-a point seldom made in the literature. Are investigators caught in the thrall of the old saw, "nothing succeeds like success"? Or, do they recursively assume, that where there is a successful outcome, there must have been a successful "method"? I leave the answers to them. Obviously, and trivially, neither of these forms of "leadership" is teachable because spurious.

One final point in this brief conceptual survey: 'leadership,' no less than 'musicianship,' or 'education,' is a value-laden term. It is one thing to lead, quite another to display qualities of leadership (whatever they may be) just as it is one thing to play, another to display musicianship, one thing to teach, another to educate. In doing the one, you may achieve the other but not necessarily. All three terms are evaluative as well as descriptive of certain procedures and accomplishments, referring to certain preferred ways of influencing people, performing on a musical instrument, or teaching. As well, the "preferred ways" of leading may not conform to our own values, as when we speak of leadership in totalitarian regimes or in societies or political movements of which we morally disapprove. In other words, ascriptions of leadership may be normative (what counts as leadership for us) or descriptive, in the anthropological sense, of other peoples' preferences (what counts as leadership for them). Normatively, the idea of "bad leadership" comes close to a contradiction in terms, though descriptively, bad leadership-meaning morally reprehensible by our own standards-is a common-place. Either way, whether we are speaking normatively or anthropologically, ascriptions of leadership presume some set of governing principles beyond the mere fact of leading. The inescapably normative character of leadership all too frequently gets buried under the weight of factual data with important consequences to be noted later on. For now, let us examine the relations among leadership, authority, and power.

\section{Leadership, Authority, and Power}

John W. Gardner offers this definition:

[Leadership is] the process of persuasion and example by which an individual (or leadership team) induces a group to take action that is in accord with the leader's purposes or the shared purposes of all. Elements of physical coercion are involved in some kinds of leadership; and of course there is psychological coercion, however mild and subtle, including peer pressure, in all social action. But in our culture popular understanding of the term distinguishes it from coercion-and places higher on the scale of leadership those forms involving lesser degrees of coercion. ${ }^{8}$

The first thing to note about this definition is that it focuses exclusively on the tasks or processes of leadership. The second thing to note is that it is a preferred definition, one reflecting a certain democratic bias and values-in effect, a "committed" view. It is, therefore, not so much descriptive of what leadership is as prescriptive of what it ought to be. Dallas' J.R. Ewing, not to mention a host of military, sports, business, and political leaders, would find Gardner's "definition" naive-more a call to high-mindedness than functional for reality. Others, more interested in results, might take a rather different view. As an antidote to such idealism, I am reminded of the remark of a dean of a major academic institution who once said to me, "A prime prerequisite of 
leadership in this game is that a part of you must enjoy saying no to people." So much for non-coercive methods.

Presumably, social scientists are in the business of studying leadership as it is, not as it ought to be. Which is to say, not that they should ignore values, but rather to describe and analyse those that are in force in any given instance. Except for the historical and biographical literature, I find precious little on the patterns of coercion, intimidation, and deception that are so prominent in real life leadership, in the "anthropological" sense aforementioned, particularly in the political and business domains. ${ }^{9}$ And that brings me to the relations of leadership to authority and power. Again, Gardner:

Authority is not the same as leadership. Authority is legitimized power, i.e., a mandate to exercise power in a certain sphere. It is official or traditional sanction for individuals occupying certain specified positions to perform certain directive acts." 10

The is fine so far as it goes, but it does not go nearly far enough. Gardner's kind of leadership is essentially consensual, based on agreement (contractual or otherwise) between the leader and the led. But that is a rare phenomenon even in democratic societies and enterprises. (I am surprised that social scientists have made so little of the fact.) Legal-traditional authority in the Weberian senses aims to bring about conformity. But failing that, the alternative is power. "To use power," says R.S. Peters, "is to get others to do what you want by force, by threats, by economic pressure, by propaganda, suggestion, and other such irrational means."11 Now we are talking J.R.'s language! So what is the difference between authority and power? Listen to Peters:

There is a very close connection between power and authority; but I think that they are concepts which belong to different families. Indeed, as de Jouvenel points out, it is only when a system of authority breaks down or when an individual loses his authority that there must be recourse to power if conformity is to be ensured. The concept of 'authority' is necessary to pinpoint ways in which behaviour is regulated without recourse to power-to force, propaganda, and threats. . It may also be the case that power is a convincing ground of entitlement as in the old saying 'no legitimacy without power.' But a necessary condition for the exercise of authority or a ground of entitlement to it should not be confused with what 'authority' means. ${ }^{12}$

So what does authority mean? Our English word 'authority' derives from the Latin auctor (the authority) and auctoritas referring "to a producing, inventing, or cause in the sphere of opinion, counsel or command." "Authority is at hand," says Peters, "where a rule is right or a decision must be obeyed or a pronouncement accepted simply because $X$ (conforming to some specification) says so. Equal emphasis must be placed on the ' $X$ ' and on the 'says'. For the reference to $\mathrm{X}$-the 'auctor'-is as necessary as the reference to the speech or symbolic gesture by means of which he lays down what is correct or decides what is to be done."13 Military orders, court decisions, umpire calls, or a pope speaking ex cathedra (literally "from the chair" as God's spokesman) are typical examples of orders.

What distinguishes such conformity to rule from the pecking order of chickens and the flying formation of ducks are symbolically mediated procedures stipulating "what standards are right and correct, who is to originate them, who is to decide about their application to particular cases, and who is 
entitled to make changes."14 Such procedures confer the right to give orders, make decisions affecting others, and to pronounce on certain matters. "The artifice of speech," says Peters, "introduces systems of conformity which have no application in the forest or farmyard." 15 What is bred in the bone of animals is not a right passed on from one generation to the next by education and training; for chickens and ducks "do not speak-let alone bave a right to speak." 16

Such a system of rights constitutes a system of authority in human cultures, and the variety of systems of authority is bewildering historically and culturally. Weber's familiar trichotomy of systems of authority into "legal," "traditional," and "charismatic" is as good a place as any to begin sorting them out, but that is not my interest here. My point is that any consideration of leadership, in any of its varieties, that ignores the historical, cultural, and systemic contexts of its occurrence is bound to mislead (pun intended). In other words, whatever typology of leadership one adopts, different spheres of leadership need also to be recognized not only in name: the arts, sciences, education, business, politics, the military. If, as I believe, we suffer from altogether too many "charismatic" figures in politics, where would the arts and sport be without them? There is no such thing as leadership apart from such contexts, and there is no one thing that constitutes leadership in any of them. Good reason, then, to be sceptical about programmes of "leadership training"-virtually an oxymoron-given how much the issues and qualities of leadership change from one context or sphere to another. But that is only the thin edge of my argument.

\section{Get the Facts, Give the Message ${ }^{17}$}

I tum now to some methodological caveats that fuel my scepticism. Recently, while perusing what educators have to say about leadership, I read a "Request for Proposal" (RFP) from a government agency in Washington, D.C., stipulating guidelines for research on leadership in education. The general tone of this RFP, like so many of its kind, was, "Give us some applied theory and recommendations with which we can drive nails." Beyond that was the suggestion throughout that leadership should be precisely defined, its distinctive traits empirically nailed down, and then implemented by training programmes in leadership "skills."

Methodologically, such an approach to the delicate topic of leadership in any sphere is logically crude, scientifically unsound, and practically simplistic. The plethora of Type III errors (precise solutions to the wrong problems) is often compounded by the narrow-bore precision of the research "instruments" employed. ${ }^{18}$ Yet many doctoral theses I have seen fall into this pattem of reductive, pseudo-empiricism, not only in leadership studies but in curriculum, management, and policy studies as well. It is a methodological "virus"-precise encounters of a misplaced kind. Whether researchers are pandering to agency and foundation preconceptions or the reverse is a chicken-and-egg question, I happily bequeath to sociologists of knowledge. Instead, I shall focus on why I find this approach to leadership studies and training so objectionable.

The root problem is treating leadership as a thing for study. Much of the current literature exhibits a tendency to reify the concept of leadership, as if it 
were some one thing, complex perhaps, but there to be netted by real definition and objective observation. The result is antique "essentialism"-the assumption that the essence of leadership can be abstracted from particular circumstances, precisely defined, and then operationalised in terms of observable activities and practices. It is as if Francis Bacon joined Aristotle in contemplating, not the bust of Homer, but of Alexander! Many pitfalls bedevil the essentialist approach to leadership.

Reification of the concept of leadership ignores the facts, mentioned at the outset, that leadership is neither univocal nor readily systematised for scientific investigation. Like creativity, intelligence, or buman potential, leadership is an everyday notion of variable meaning and application rather than a scientific concept of fixed meaning. Accordingly, leadership and its cognates such as authority, power, influence, responsibility, accountability, cry out for conceptual analysis, not genus and species definition. Then, depending upon one's theoretical and practical goals, the concept may be reconstructed for certain purposes.

Some reconstructions are for purely theoretical purposes. Euclid, for example, did not arrive at his conception of a point as that which has location but no magnitude by taking polls or examining samples of "real life" points. Neither do work, force, and mass in Newtonian mechanics have much to do with the everyday connotations of those terms. Other reconstructions are intended, rather, to systematise the everyday meanings of concepts in order to make them more amenable to study or for theoretical use-again, the examples of creativity, intelligence, even education itself come to mind; but they are no less reconstructions subject to constant scrutiny and revision within the context of what Scheffler calls a "practical theory" intended to relate scientific knowledge to practical interests. ${ }^{19}$

Reification further engenders a native behaviourism to the effect that leadership strategies can be operationalised in terms of observables such as "behaviours," "activities," and "practices" (perhaps by videotape, anecdotes, interviews, and questionnaires). These are then codified and presented as the latest "bag of tricks" for analysing and teaching leadership. A host of "how to"' leadership books in education, business, and politics exemplify this pattern, not a few of them suggesting that what is good, say, for GM or Kodak would be good for American education. Even if found to be typical of many instances of leadership in this or that context, such trait lists are unlikely to be necessary or sufficient for leadership in any broadly applicable way. (A similar logical gap characterises the literature on creativity and critical thinking.) As well, this approach entirely ignores the more inchoate, covert, or passive types of leadership: by example (positive or negative), by subtle suggestion, or by indirection, to mention only three.

\section{A Technology of Leadership?}

Beyond reification and its liabilities, the leadership literature also tends to identify leadership with incumbents of institutional roles such as presidencies, principalships, CEOs, and superintendencies. It goes without saying that leadership exists in powerful forms elsewhere, often primarily elsewhere, in advisory or consulting capacities, in the development and communication of ideas, in artistic, scientific, literary, or religious example. Such identification of leadership with directive roles and their incumbents confuses the "is" with the 
"ought" of leadership and plays directly into the aforementioned essentialism and "bag of tricks" approach to practice: first, find out who is "succeeding" in a particular role by a stipulated set of criteria; second, codify the requisite behaviour by one or other analytical "model"; and then, third, recommend these behaviours as the key to success in a kind of "technology" of leadership. While seeming to temper the wind to the shorn lamb, such research tactics end by slaughtering the lamb. Not so easy are questions of value and choice, of judgement and understanding, and of sheer time and chance dismissed or rendered down.

The oft-sounded call for "effective" leadership implies values. While values are sometimes acknowledged superficially, ${ }^{20}$ the urge to reduce leadership to simple observables, on the one hand, and to make "technical" recommendations for its achievement on the other (as if a technology of leadership were possible) submerge the crucial role of values both in the execution and in the assessment of leadership in any domain. ${ }^{21}$ Unless the ethical issues of leadership are made explicit and faced squarely, the tendency is to become captive of whatever (unexamined) values or prejudices drive current practice. McCaulley ${ }^{22}$ hints at that problem but only in passing in her examination of the attraction of certain personality types to leadership positions of various kinds. The most practical thing to be done here is to become as clear as possible about the controlling values and principles that govern how leadership actually is exercised as contrasted with espoused values of how it ought to be exercised. At the risk of labouring the point, I say again that, like 'education,' 'leadership' is seldom used in a purely neutral, descriptive fashion. It is a value-laden word referring not only to what is done but to certain preferred ways of doing it. 23 In short, effectiveness without normative clarity is morally blind, like much ambition.

The aforementioned caveats can be summarised in terms of three "myths" of leadership that appear to afflict the current literature on the subject. First is the myth of an abstract, fixed essence of leadership to be distilled by neutral scientific observation and stipulative definition. Second is the myth of compatible (nonconflicting) characteristics of leadership constituting the "bag of tricks" by which it may be managed and taught. Third is the myth of "good" leadership-the honorific use of the term that assumes that real leadership is always laudable and conforms to one's own moral preconceptions. (I am reminded of those endless debates among critics over what is really art, music, or literature, in which questions of identity and of merit are persistently confounded.) Such "mythology" is more scientistic than scientific, more on the order of self-fulfilling prophecy than genuine discovery.

\section{Leading Questions About Leadership}

Before returning to my main question which is whether leadership can be taught, I want to suggest some non-Type III questions for consideration. The first questions for anyone undertaking to study leadership, or any other controversial (because vague and ambiguous) notion, are: What does leadership, the term, mean? What is its history of usage in various contexts and in relation to its cognates? What theories and practices of leadership have most influenced how we now use the term? What values attach to the different usages of the term? What practices accrue to different conceptions of leadership? 
These are not questions answerable by consulting any dictionary, positing stipulative categories, or by passive rehearsal of the "isms" and "wasms" of leadership past. Rather, such questions require conceptual and logical analysis of the various prevalent (and, no doubt, conflicting) conceptions and treatments of the notion of leadership, say, from Classical times to the present. As said, the aim here is not to write the history of the concept of leadership (a useful enterprise, to be sure) but to plunder that history for purposes of philosophic and scientific discovery-in effect, to construct a "practical theory" of leadership.

Besides analysis and criticism of extant notions of leadership, a further aim would be to provide new mappings of the many domains of leadership, not only in business, education, the military, and government, but in many other realms and not only by reference to directive roles. The goal is, in Ryle's phrase, "rectification of the logical geography" 24 of the concept through comparative analysis of leadership and related ideas such as authority, power, responsibility, accountability, judgement. Writers on leadership from Plato to Weber attempted to do just that for their own, but I see little effort in that direction in the educational literature on leadership. Rather, the assumption seems to be that in some inchoate way we already know what leadership is ("getting the job done," or "influencing others to conform"), and we have only to figure out how certain incumbents "managed" their successes to be able to measure the "leadership potential" of aspirants. Few of the documents and proposals that I have seen register the fact that the quest for a technology of leadership is as quixotic as the quest for a "logic" or technology of discovery in science. $^{25}$

In short, I recommend that an analytical survey of the history of ideas of leadership be undertaken, not as a preliminary, but as a constant ingredient of its scientific study. That is probably the quickest cure of the methodological difficulties already mentioned. That involves study of the tradition of theories of leadership in philosophy and political theory from Plato and Aristotle to Weber and beyond by reference to what actually happens in specific domains. The idea is to put the entire topic in broad historical comparative perspective. The therapeutic value of such an analysis would be to reveal the unacknowledged sources of contemporary ideas of leadership (including their values and biases) and to show how those sources continue to influence present thinking about the subject. The result to be expected would be an access of freedom in conceptualising leadership for scientific and practical purposes. Now let me return to my original question.

\section{Can Leadership be Taught?}

The idea of leadership training strikes me as oxymoronic as training in musicianship. Training has to do with specific skills, techniques, strategies, and only marginally with judgement, imagination, and values. ${ }^{26}$ Training, you might say, is task-specific. The analogue of music training (e.g., in reading notation, keyboard technique) is training in particular strategies and tactics of leading (e.g., a meeting, a political campaign), not leadership, as such. Well, what about leadership education? Surely it makes sense to say that one has been educated, however it is done, in leadership or musicianship, that one has learned it, discovered what it means, how to do it. Ergo, it can be taught. Ah, but already we have shifted ground from teaching in the sense of specific instruction 
(or training) to a sense of teaching that is virtually coextensive with learning, with self-teaching, with all that we manage to induce from experience, training, and accumulated knowledge-in a word, savoir vivre. So, leadership is knowledge in the way that Plato argued that virtue is knowledge? I think not, and I will attempt to show why. In the dialogues Protagoras and Meno, Socrates raises the question whether virtue can be taught. Now this is not virtue in any narrow sense having to do with sexual conduct, but arete, better translated as "excellence" which, applied to human beings, connotes "the acquisition of political and private savoir vivre"27 - what we might nowadays call leadership. The fifth century B.C. Athenian counterparts of modern teachers of leadership were the Sophists who purported to teach arete to any and all who could afford their fee. When queried by Socrates what a young man could expect to leam, Protagoras, the most distinguished Sophist of his day, replied, "The proper care of bis personal affairs, so that he may best manage his own household, and also of the state's affairs so as to become a real power in the city, both as a speaker and man of action."28 Unlike Gardner's earlier quoted highminded definition of leadership, Protagoras' statement is entirely achievement centred. He promises to deliver precisely what his clientele want which is training in leadership that works. His is the "bottom line," "how-to" perspective without apologies.

Socrates is sceptical for the reason, as one commentator puts it, "that Socrates did not regard education and philosophy as a training in how to do things, but as a process of acquiring a knowledge of things."29 "So what?" you might ask. So education and philosophy are not training, but that does not imply that leadership cannot be trained or taught. Socrates' famous reply is that virtue (arete) is knowledge and that to know the good is to do the good. As Gutherie remarks,

When they (the Sophists) claimed to teach virtue they had nothing of that sort in mind, but only a purely practical and empirical training. His (Socrates') procedure on the other hand was based on a passionate conviction that the knowledge could be attained, and moreover that the only way to reform conduct was to lead men to an understanding of certain permanent and unvarying principles on which to base it. ${ }^{30}$

Paradoxically, modem social scientists seem to occupy both sides of the argument: namely, that if more were known about leadership, then it could be trained. Now I cannot agree that knowledge of leadership is sufficient to lead; for if that were so, then, social scientists, philosophers, and historians would be the best qualified to lead as latter-day philosopher kings. Nor do I accept Plato's pre-natal theory of knowledge in which knowledge, pre-existing in the soul, is merely elicited by triggering experiences and questions. ${ }^{31}$ That is not why I think leadership cannot be taught because, as a form of arete, it is innate. Still, I agree with Socrates that however much is known about leadership, it cannot be taught in ways that conform to any programme of instructional "how to."

Why not? Recall my earlier observation that the concept of leadership, like that of creativity, is value-laden and not a neutral, descriptive term. What this means inter alia is that judgements of leadership, like judgements of creativity, tend to be evaluative of the merit of results achieved (by whatever standards). For example, if someone says, "I am writing," "I am painting," "I am thinking," you might well reply, "Yes, I can see that." But if he or she had 
said, "I am creating," you would be justified in replying, "How can you be sure? Let's wait and see.",32 Similarly, "I am leading," and "I am exercising leadership," refer to quite different things, the former to an observable event, the latter to an assessment of that event. In effect, leading does not imply leadership any more than writing implies creating.

Well, what about so-called "creative-process," or "leadership process"'? To judge a process or procedure as "creative" or an instance of "leadership," I submit, is a recursive judgement, a projection backwards, as it were, to whatever led up to the meritorious result (again, by whatever standard). And that could be anything including pure accident. In other words, leadership is not an isolable activity in the way that some forms of leading may be. There is no specifiable process such that " $X$ is an instance of leadership" entails "Process $P$ has occurred." What can we conclude from all this? What can or cannot be taught about leading and leadership?

First, much propositional knowledge ("knowledge that") about leading and leadership can be taught by social scientists, historians, biographers, philosophers, and others. Which is to say that both leading and leadership are proper topics of study, the results of which are transmissible in propositional form and may well prove informative to aspiring leaders.

Second, much procedural knowledge ("know-how") about leading-particular strategies, tactics, skills-can also be taught by a variety of instructional means: training, drill, case study, practice, and example. ${ }^{33}$ Many critical skills and routine facilities are, thus, communicable that may or may not result in the achievement of leadership by those who master them.

What cannot be taught, I contend, is leadership as such any more than creativity or discovery as such can be directly taught as procedures, as items of "how-to." To speak of techniques of leadership, creativity, or discovery is either oxymoronic or to refer to those techniques of leading, of artistic activity, or of inquiry that one hopes, perhaps even reasonably expects, will now and again issue in something noteworthy. In sum, both leading and leadership can be taught propositionally in fact and theory; leading can be taught procedurally, as practical "how-to"; but not leadership as practical procedure. Hence, I agree with Socrates but for very different reasons.

But surely, you will say, leadership, like musicianship, for example is learned. Cannot it therefore be taught? Well, not everything that is learned is taught, but that is too easy a way around the question. I grant that leadership, like musicianship, is learned and that both may occur partly as a result of what one was taught. It may also be thwarted by what one was taught.

Take musicianship. Musical training inevitably includes much information and knowledge, many hours, perhaps years, of practice and drill, performance experience, examination of the examples provided by others including their styles, successes and failures, and a good deal of persistence and interpretive reflection upon the specific musical challenges undertaken. The key phrase here is 'interpretive reflection' for nothing is given in instruction but is also taken, interpreted, construed by the learner in ways that go quite beyond the control of the teacher or the routines and facilities mastered. That goes as much for the novice's finger drills, at one extreme, as for the virtuoso's final dress rehearsal, at the other. ${ }^{34}$ However, the room for interpretive nuance, for the exercise of personal choice, judgement, and imagination increases with growing 
competence, as one facility embeds within another, as one finds one's own way of doing things. Eventually, one is up against not limitations of technical facility and skill, but the limits of one's own personality, judgement, and imagination. Include in that the particular choices made en route, say, of instrument, repertoire, teachers, and performance opportunities.

Whether an individual will achieve a certain level of musicianship after all depends as much upon time and chance as upon everything that one has learnt and done. While we often hear virtuosi say such things as, "I learned everything from my teacher," or "Julliard helped me find my own voice," what they do not mean is that the referred teacher or Julliard gave them their own voice or superior interpretive abilities. To say that a particular teacher, programme of instruction, or institution "taught me musicianship," is to speak metaphorically. It is to say that without such guidance, I might not have found it for myself; for that is ultimately what must happen; the discovery, the achievement, is one's own, not a direct product of instruction or teaching of any kind. Otherwise, every graduate of Julliard or student of a particular teacher would be a virtuoso.

Now leadership is very similar to musicianship in that regard. While it cannot be taught directly, it can be learned depending upon the interpretive abilities and practical opportunities of the learner given everything that has been taught. If this sounds banal and obvious in the final saying, then the foregoing analysis has been successful; and one wonders why these simple insights are not more clearly reflected in the leadership literature and in the proliferation of so-called "leadership training" programmes.

Allow me to end with a personal anecdote. Recently on the $C B C$, I heard a young tenor singing Strauss songs. His voice strongly resembled my own. As a one-time professional singer, I was naturally interested. As I listened, I was struck not only by the timbral similarity to my own voice but by his extraordinary musicianship. His grasp of the texts, the ways be attacked and turned phrases was so superior to my own as to be humbling. I thought, that might have been me but for. . .what? Our training was comparable. I have the same technical control and range as he. I have studied the same Straussean texts in German. But as I listened, it became apparent that I lack the expressive judgement, imagination, and sheer insight into the music that he possessed and exemplified in one stanza after another. I envied him even as I understood and appreciated what he was doing, as only someone trained in singing could do.

Was he taught? Obviously, many things, but nothing of what he accomplished in that performance was reducible to routine, however many hours of instruction and practice at technical facilities were involved. And that is my point about arete in any of the many forms it takes: it is learned, it is done, but it is not taught. 


\section{Notes}

${ }^{1}$ W.G. Bennis, "Leadership Theory and Administrative Behavior: The Problem of Authority," Administrative Science Quarterly, 4, 1959, 259-260; R.M. Stogdill, Handbook of Leadership, (New York: Free Press, 1974), J. Pfeffer, "The Ambiguity of Leadership," in Morgan W. McColl, Jr. and Michael M. Lombardo (eds.), Leadership, Where Else Can We Go? (Durham: Duke University Press, 1978); Peter B. Vaill, "Toward a Behavioral Description of High Performing Systems," in Morgan M. McColl, Jr. and Michael M. Lombardo (eds.), op. cit.

${ }^{2}$ R.M. Stogdill, op. cit., vii.

${ }^{3}$ C. Perrow, Complex Organizations: A Critical Essay (Glenview: Scott, Foresman, 1972): J.B. Miner, "The Uncertain Future of the Leadership Concept: An Overview," Presented at the Third Leadership Symposium, Southern Illinois University at Carbondale, March, 1975.

${ }^{4} O E D$.

${ }^{5} O E D$.

${ }^{6}$ Gilbert Ryle, The Concept of Mind, (Chicago: University of Chicago Press, 1984), 150.

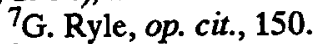

${ }^{8} \mathrm{John}$ W. Gardner, The Nature of Leadership: Introductory Considerations (Leadership Papers/1: Independent Sector, 1986), 6.

${ }^{9}$ An exception is Robert B. Cialdini's Influence (New York: William Morrow, 1984).

${ }^{10}$ John W. Gardner, Leadership Development (Leadership Papers/7: Independent Sector, 1988), 7.

${ }^{11}$ R.S. Peters, Authority, Responsibility and Education (second edition) (London: Allen and Unwin, 1963), 20.

${ }^{12}$ Ibid., 21.

${ }^{13}$ Ibid., 15.

${ }^{14}$ Ibid., 14.

${ }^{15}$ Ibid.

${ }^{16}$ Ibid., 15.

${ }^{17}$ This and the following two sections, now considerably revised, originally appeared in Chinese translation of "Leadership Studies: Social Science Fiction?" Journal of East China Normal University, 4, 1990, 19-22.

${ }^{18}$ Cf. Michael M. Lombardo and Morgan W. McColl, Jr., "Leadership," in Morgan W. McColl and Michael M. Lombardo (eds.), op. cit., 3.

${ }^{19}$ See Israel Scheffler's Of Human Potential (London: Routledge and Kegan Paul, 1985) for an example of such a reconstruction for scientific and practical purposes.

${ }^{20}$ John W. Gardner, The Moral Aspect of Leadership (Leadership Papers/2: Independent Sector, 1987).

${ }^{21}$ Musicians, for example, routinely distinguish between technical proficiency and "artistry" as a form of aesthetic judgement. The parallel to leadership is by now obvious.

22 Mary H. McCaulley, "The Myers-Briggs Type Indicator and Leadership," in Kenneth E. Clark and Miriam B. Clark (eds.), Measures of Leadership (West Orange, N.J.: Leadership Library of America, 1990). 
${ }^{23}$ Cf. R.S. Peters, "What is an Educational Process?' in R.S. Peters (ed.), The Concept of Education (London: Routledge and Kegan Paul, 1967).

${ }^{24} \mathrm{G}$. Ryle, op. cit..

${ }^{25}$ Norwood Russell Hanson, Patterns of Discovery (Cambridge: Cambridge University Press, 1958); Karl Popper, The Logic of Scientific Discovery (London: Hutchinson, 1959).

${ }^{26}$ See V.A. Howard, Learning By All Means: Lessons From the Arts (New York: Peter Lang, 1992), chapter 5.

27 Plato, Protagoras and Meno, translated with an introduction by W.K.C. Gutherie (London: Penguin, 1956), 18.

${ }^{28}$ Plato, op. cit., 50 (319A).

${ }^{29}$ T.A. Sinclair, A History of Greek Political Thought (London: Routledge \& Kegan Paul, 1951), 94.

30Plato, op. cit., 15.

${ }^{31}$ Ibid., 129.

32V.H. Howard, Artistry: The Work of Artists (Indianapolis: Hackett, 1982), 120.

${ }^{33}$ On the differences between propositional and procedural knowledge, see I. Scheffler, The Conditions of Knowledge (Chicago: University of Chicago Press, 1965), 1416: V.A. Howard, Artistry: The Work of Artists (Indianapolis: Hackett, 1992), 178.

${ }^{34}$ V.A. Howard, Learning By All Means, op. cit., Part III. 